Avoimesti luettavissa osoitteessa http://journal.fi/ainedidaktiikka

\title{
Social hållbarhet och scientific literacy i flerspråkiga naturvetenskapsklassrum
}

\author{
Sari Vuorenpä̈̈ ${ }^{1}$, Lili-Ann Wolff ${ }^{2}$ och Pia Sjöblom ${ }^{3}$ \\ ${ }^{1}$ Institutionen för språkdidaktik, Stockholms universitet \\ ${ }^{2}$ Pedagogiska fakulteten, Helsingfors universitet \\ ${ }^{3}$ Fakulteten för pedagogik och välfärdsstudier, Åbo akademi
}

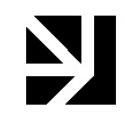

Den här artikeln fokuserar på social hållbarhet som undervisningspraxis, inte som undervisningsinnehåll, närmare bestämt hur den naturvetenskapliga undervisningen kan förverkligas på ett socialt hållbart sätt. Forskningsfrågan är hur lärare som undervisar i naturvetenskaper kan erbjuda elever mer likvärdiga förutsättningar att utveckla scientific literacy. Vi sökte svaret med stöd av klassrumsobservationer i Finland och Sverige. I resultatet utkristalliserade sig särskilt fyra kategorier med relevans för social hållbarhet $i$ undervisningen: språkanvändning, konkretisering, tidsanvändning och uppmuntran till elevinitiativ. Ett likvärdigt lärande i naturvetenskaper kräver en didaktik där målmedvetet språkbruk sammanflätas med konkreta lärandesituationer utan tidspress. Det är även ett lärande där elevinitiativ tillvaratas.

Social hållbarhet, hållbarhetspedagogik, ämnesspråk, scientific literacy, naturvetenskapernas didaktik

Sänt: 4.5.2020

Godkänt: 22.10.2020

Ansvarande artikelförfattare: lili-ann.wolff@helsinki.fi

DOI: $10.23988 /$ ad.97377 


\section{Introduktion}

Hållbar utveckling är en process som leder till ett mer hållbart samhälle. Hållbarhet som samhällsmål har fyra dimensioner: ekologisk, ekonomisk, social och kulturell, där social och kulturell ofta ses som en dimension (t.ex. Roosa, 2008; Unesco, 2012). Social hållbarhet betecknar mänskligt välbefinnande $\mathrm{i}$ en gemenskap som bygger på rättvisa och demokrati (Missimer, Robèrt \& Broman, 2017) samt värnar om kulturell mångfald och jämställdhet (Boström, 2012). Det socialt hållbara samhället är rättvist och inkluderande (Eizenberg \& Jabareen, 2017) och alla medborgare har möjlighet att leva ett liv i frihet (Littig \& Grießler, 2005). Social hållbarhet inbegriper grundläggande rättigheter att påverka och få utbildning (Larsen, 2008). Möjligheten att få utbildning innebär även likvärdig rätt att tillägna sig naturvetenskaper, vilket denna artikel utreder närmare.

Utbildning, inklusive hållbarhetsutbildning, är en grundläggande mänsklig rättighet och sammantvinnad med andra mänskliga rättigheter (Sanchez Moretti, 2015; Unesco, 2019). Utbildning är grunden för aktiva och hållbara val i olika livsskeden. De naturvetenskapliga ämnena ger omvärldsförståelse och utvecklar nyfikenhet och tänkande. Lärarna inom dessa ämnen har traditionellt fått ansvara för i synnerhet de ekologiska hållbarhetsfrågorna (t.ex. Borg, Gericke, Höglund \& Bergman, 2012; Uitto \& Saloranta, 2012). Mycket av det som berör hållbarhet ingår innehållsmässigt i de naturvetenskapliga ämnena enligt läroplanerna i Finland och Sverige, men dessa ämnen behöver också utformas så att undervisningen i sig är hållbar, även socialt (Wolff, Vuorenpää \& Sjöblom, 2018). Såväl det lärande som sker i klassrummet som det skolspråk som används kan endera förstärka eller utmana den sociala rättvisan (Wrigley, Lingard \& Thomson, 2012).

Den didaktiska forskningen har alltmer aktualiserat och uppmärksammat rättvise- och jämställdhetsfrågor (Helldén, 2009) samt fokuserat på läroplaner som bygger på en mer rättvis epistemologi (Mudlay, 2020). Centrala frågor, såsom demokrati och ansvarsfullt medborgarskap, kräver kritiskt tänkande och argumenteringsförmåga (Mudlay, 2020). De didaktiska vägvalen påverkar hur socialt hållbar undervisningen är. Genom övervägda val kan läraren skapa möjlighet för alla elever att utveckla en kritisk scientific literacy (se nedan) och bli delaktiga i den naturvetenskapliga diskursen. Om naturvetenskaperna däremot kommuniceras ensidigt, kan det leda till social reproduktion och marginalisering av vissa samhällsgrupper och -medlemmar (Pearson, Moje \& Greenleaf, 2010).

Syftet med denna studie är att undersöka hur undervisningen i naturvetenskaper kan förverkligas på ett socialt hållbart sätt. Med socialt hållbart avses här likvärdiga förutsättningar för eleverna att lära sig. Studien utgår från frågan: Hur kan lärare som undervisar i naturvetenskaper erbjuda elever mer likvärdiga förutsättningar att utveckla scientific literacy?

En av forskningens uppgifter är att synliggöra hur läraren gör sina didaktiska val (Sund, 2008). För att besvara forskningsfrågan har vi analyserat lärarens didaktiska val och interaktionen i två klassrum där naturvetenskapliga ämnen stod på schemat. Resultaten kan 
förhoppningsvis även bidra till att fördjupa förståelsen av några aspekter av betydelse för social hållbarhet inom andra ämnesområden.

\section{Social hållbarhet $\mathrm{i}$ utbildning och lärande}

De globala utvecklingsmålen i Agenda 2030 fokuserar speciellt på den sociala dimensionen av hållbarhet (UN, 2015). Faktorer som mänskliga rättigheter och jämlikhet står i centrum. Utbildningen ska utgå från en hållbar etik och utveckla metoder som ger alla människor likvärdiga möjligheter att bli delaktiga i samhällsutvecklingen. Trots att varken de finländska läroplansgrunderna eller den svenska läroplanen för den grundläggande utbildningen explicit redogör för vad social hållbarhet $\mathrm{i}$ utbildning och skola innebär, betonas denna dimension i vardera läroplanen (Skolverket, 2019; Utbildningsstyrelsen, 2014). De finländska läroplansgrunderna betonar att eleverna ska få uppleva jämlikhet, delaktighet och samhörighet, medan den svenska läroplanen betonar att "undervisningen ska bedrivas $i$ demokratiska arbetsformer" (Skolverket, 2019, s. 6, artikelförfattarnas kursivering av "i"). Biesta (2003) ser demokrati som ett utbildningsproblem i sig och gör skillnad mellan lärande som demokrati (fokus på lärandeprocesser) och lärande om demokrati och demokratiska processer (fokus på kunskapsinnehåll). Denna skillnad gäller även lärande om hållbarhetsfrågor (se Rieckman, 2018). Hållbarhetspedagogik handlar följaktligen inte enbart om innehållsmässig ämneskunskap, utan också om att didaktiskt stödja utvecklingen av en lärmiljö grundad på social hållbarhet.

En faktor som påverkas av såväl val av innehåll som av arbetssätt är elevernas socialisation. I lärandet är det inte alltid möjligt att särskilja innehållet från socialisationen, utan de bildar en sammansatt helhet, enligt Sund (2008). Genom språk och handlingar förmedlar läraren följaktligen värderingar, och ger en bild av hur kunskapen förhåller sig till omvärlden. Likaså kommunicerar lärarens val vilka maktförhållanden som råder mellan lärare och elev, samt vilket ansvar eleven har för det egna lärandet och som samhällsmedlem.

Läroplanerna i Sverige såväl som i Finland betonar att eleverna ska uppmuntras till att vara delaktiga och ta egna initiativ (Opetushallitus, 2020; Skolverket, 2015). Genom att lärarna involverar eleverna i det som sker i klassrummet, skolan och närsamhället samt gör dem delaktiga i undervisning och lärande uppfylls en del av skolans demokratiuppdrag (se t.ex. Rönnlund, 2013). Eleverna ska därför ges möjlighet att ta initiativ i frågor som berör dem (Skolverket, 2015). Läraren kan uppmuntra eleverna till att vara innovativa, ta initiativ och förverkliga sina idéer, samt utvärdera resultatet (Peko \& Varga, 2016). Lektionerna i naturvetenskap blir då lärandesituationer som tillvaratar elevernas styrkor och intressen och som stöder deras identitetsutveckling (Trauth-Nare, 2016) och scientific literacy.

\section{Literacy och scientific literacy som en del av en likvärdig utbildning}

Literacy kan definieras på flera olika sätt. Förenklat handlar det enligt Blikstad-Balas (2016, s. 15) om "å skape mening ved hjelp av ulike tegn i egne och andres tekster", vilket hon förtydligar med att det innefattar mycket mer än att kunna avkoda bokstäver för att kunna läsa och skriva $i$ teknisk bemärkelse. I ett vidare perspektiv är literacy en förutsättning för 
att en person aktivt ska kunna medverka som samhällsmedborgare (Unesco, 2004). I forskning om literacy understryks ofta två perspektiv, nämligen ett sociokulturellt och ett kognitivt. Det sociokulturella ser huvudsakligen literacy som en social praktik, medan det kognitiva perspektivet har fokus på individens möte med texter. Dessa två forskningstraditioner är inte nödvändigtvis konkurrerande inriktningar (Blikstad-Balas, 2016), utan kan snarare anses komplettera varandra. Globalisering och en ökad kulturell diversitet gör att literacy kommit att beteckna ett komplext lärande som är multimodalt, mångkulturellt och flerspråkigt (Allison \& Goldman, 2018).

Under årens lopp har också definitionerna av begreppet scientific literacy varit många och det råder ingen konsensus internationellt (Smith, Loughran, Berry \& Dimitrakopoulos, 2012). Olika aktörer har även haft olika syn på hur scientific literacy mäts (Laugksch, 2000). Scientific literacy implicerar att en person behöver känna till och förstå vetenskapliga begrepp och processer som krävs för att ta beslut i vardagslivet och delta i diskussioner om samhällsfrågor (National Research Council, 1996; OECD, 2003). Enligt OECD (2003, s. 133, förf. övers.) innebär scientific literacy "förmåga att använda vetenskaplig kunskap, identifiera frågor och dra evidensbaserade slutsatser för att förstå och bidra till beslut som gäller naturen och de förändringar som mänsklig verksamhet förorsakar i naturen".

Det kan vara en utmaning för elever med annat modersmål än undervisningsspråket att utveckla scientific literacy. I Sverige har TIMSS (Trends in International Mathematics and Science) -undersökningarna bekräftat att elever med icke-svenskfödda föräldrar har ett sämre utgångsläge. I årskurserna 4 och 8 förekommer stora kunskapsskillnader i naturvetenskapliga ämnen mellan elever som är födda i Sverige med minst en svenskfödd förälder och elever födda utomlands eller i Sverige vars bägge föräldrar är födda utomlands. Forskning visar att en anmärkningsvärd del av skillnaderna beror på olikheter i socioekonomisk status, t.ex. förklaras en tredjedel av kunskapsskillnaderna i naturvetenskaper av indexet "hemresurser för lärande" (Skolverket, 2016), det vill säga i vilken mån hemmiljön stöder lärandet.

Utbildning är ett av de viktigaste verktygen för inkludering. Därför behöver undervisningen i naturvetenskaper sträva efter att likvärdigt inkludera alla elever i den vetenskapliga samhällsdebatten. Risken är annars stor att grupper marginaliseras och hamnar utanför den naturvetenskapliga diskursen (Dawson, 2018). Inkluderingen av alla elever i de naturvetenskapliga ämnena i det svenska låg- och mellanstadiet lämnar dock mycket övrigt att önska, även om det finns undantag (Skolinspektionen, 2017). Också i Finland beskrivs motsvarande utmaningar. De finländska lärarna har orsak att förkovra sig för att kunna garantera jämlika möjligheter till lärande åt alla elever (Vettenranta, Hiltunen, Nissinen, Puhakka \& Rautopuro, 2016).

En intervjustudie i USA (Southerland, Gallard \& Callihan, 2011) visar att detaljerade lärandemål som är fastställda i läroplaner och underförstådda i läroböcker omöjliggör en likvärdig undervisning, då övergripande mål som scientific literacy fick ge vika för mer specifika mål. Många lärare såg också sin egen etnocentrism som en begränsande faktor 
som bidrog till att läraren hade svårt att förstå eleverna. Klassrumspraktiken borde ta hänsyn till elevernas kultur, språk och sätt att tänka för att elever med olika kulturell bakgrund ska kunna tillgodogöra sig naturvetenskaper på ett ändamålsenligt sätt (se även Allison \& Goldston, 2018).

\section{Lärande, språk och tänkande}

Liksom i andra ämnen, sker även en socialiseringsprocess $i$ undervisningen i naturvetenskaper. Utveckling och lärande förverkligas när individen konfronteras med olika repertoarer av praxisformer, som överlappar eller kompletterar varandra. Skolan med strikt ämnesindelning inhyser många praxisformer och diskurser, vilket gör det särskilt utmanande för elever med annan kulturbakgrund än majoritetens (Nasir, Rosebery, Warren \& Lee, 2006).

Naturvetenskaperna kräver ett specifikt sätt att tänka och resonera (McNeill, 2011). Elever med annan språklig bakgrund än undervisningsspråket är i behov av att både lära sig ett vardagligt språkbruk och att förstå att skolans ämnen kräver ett ämnesspråk, så också de naturvetenskapliga ämnena (Lemke, 1990; McNeill, 2011; Wellington \& Osborne, 2001). Typiskt för vardagsspråket är att det är konkret och spontant, medan skolspråket oftare är skriftligt, monologiskt och abstrakt (Liberg, Geijerstam \& Folkeryd, 2010). I undervisningen i naturvetenskaper kan språkvariationen beskrivas med de tre begreppen vardagligt språkbruk, skolspråk och naturvetenskapligt språk. Språkvariationen kan enligt Yore och Treagust (2006) skapa förvirring om ord och begrepp från de olika "språken" används växelvis, mer eller mindre medvetet, i undervisningen.

När elever med annat modersmål än majoritetsbefolkningens ges möjligheter att använda ett ämnesspråk under naturvetenskapslektionerna presterar de bättre (Hägerfelth, 2004). Eleverna möter även världen utanför skolan. Deras scientific literacy byggs således upp i skolan och på fritiden i såväl en reell som en virtuell omgivning (Moje, McIntosh Ciechanowski, Kramer \& Collaze, 2004). Det vardagliga språket räcker inte alltid till för att eleverna ska kunna tillägna sig naturvetenskaperna. Skolans uppgift är därför att hjälpa eleverna tillägna sig det naturvetenskapliga språket (Ribeck, 2015). Genom att lärare är lyhörda och inkluderande inför elevernas tidigare erfarenheter, stimuleras eleverna att utveckla scientific literacy (Tan, Barton, Turner \& Gutiérrez, 2012).

Lärarna är i behov av att utveckla djupare kunskaper om elevernas lärande och naturvetenskapernas didaktik för att bättre kunna stödja flerspråkiga såväl som enspråkiga elevers språk- och kunskapsutveckling i dessa ämnen (se t.ex. Buxton \& Lee, 2014; Karlsson, Nygård \& Jakobsson, 2016). Detta underlättas av att lärarna förstår hur scientific literacy relaterar till språk och språkutveckling. Dessutom är det av vikt att lärarna känner till elevernas värld utanför skolan och den kunskap de möter där (Moje et al., 2004; Nasir et al., 2006). Eleverna ska inte enbart stöttas verbalt utan det är även viktigt att uppmärksamma olika typer av multimodalt stöd (t.ex. gester, såsom pekningar, och fysiska artefakter, såsom film) (Allison \& Goldston, 2018). Användning av olika modaliteter och integrering av literacyaktiviteter i det naturvetenskapliga undersökande arbetssättet stöder undervisning och lärande i naturvetenskaper (Ødegaard, Haug, Mork \& Sørvik, 2014). En integrering av literacy och 
naturvetenskaper i undervisningen ger synergieffekter i fråga om lärande på bägge områdena (Cervetti, Barber, Dorph, Pearson \& Goldschmidt, 2012). Centrala begrepp och textinnehåll kan med fördel konkretiseras genom olika experiment, bilder, modeller och annat (Ribeck, 2015). Följaktligen får eleverna erfara det naturvetenskapliga språket såväl muntligt som skriftligt (af Geijerstam, 2006) samt konfronteras med ämnesvokabulären och begreppen i många olika former (Gámez \& Lesaux, 2015).

Hur scientific literacy utvecklas relaterar också till tidsanvändning. Jarvis (2004) särskiljer mellan det snabba icke-reflekterande lärandet och det långsamma reflekterande lärandet. Medan det icke-reflekterande är tämligen statiskt och memorerande, kan det reflekterande lärandet åstadkomma förändringar. Således leder det snabba lärandet lätt till reproducering av kunskap. Läraren kan demonstrera sin makt genom att välja det snabba icke-reflekterande lärandet framför det mer tidskrävande reflekterande (Jarvis, 2004).

\section{Metod}

Studien är en kvalitativ fallstudie som ger möjlighet att analysera komplexiteten i en given situation (Denscombe, 2016). Fallstudier kan svara på frågor om vad som sker, hur det sker och problematisera varför det sker (Denscombe, 2016; Yin, 2003). Den kvalitativa fallstudien utmärks enligt Merriam (1994) av att den är partikularistisk, deskriptiv, heuristisk och induktiv. Partikularistisk innebär i denna studie att undersökningen riktas mot några elevgrupper en avgränsad tid, medan deskriptiv inbegriper att situationerna vi undersöker är detaljerat beskrivna. Heuristisk betyder i denna studie att vi avser att ge läsaren en bättre förståelse av det aktuella fenomenet social hållbarhet och det induktiva består av att det insamlade materialet utvecklar en djupare förståelse utan att vara teoriprövande.

Studiens empiri är insamlad under sammantaget tre veckors tid år 2018 i förortsskolor med flerspråkiga elever i såväl Finland som i Sverige. Observationerna har skett inom grundskolans årskurs 5, men studien är inte komparativ, utan ger exempel från klassrumskontexter i båda länderna. Samtliga deltagande lärare, elever och elevers vårdnadshavare fick information om forskningsprojektet och har godkänt att vi bedrivit forskning i klasserna. I båda länderna har även etikprövning genomförts och godkänts. Två av forskarna har besökt samtliga skolor, medan den tredje har tagit del av klassrumsinteraktionen i transkriberad form. Urvalskriteriet var att hitta förortsskolor där även flerspråkiga elever skulle ingå.

Vi har valt att presentera och analysera interaktionssekvenser från lektioner med människokroppen, bakterier och hönsuppfödning som teman. Resultaten baserar sig även på samtalssekvenser med lärare och elever utanför lektionstid. Studien ser på språkanvändning som något som är situerat, varför exemplen visar autentiska samtalssituationer. Att välja att göra videoobservationer är ett ställningstagande i sig, där den som styr kameran konstruerar materialet tillsammans med kameran. Det första analysvalet sker därmed redan när kameran riktas. Inspelningarna är 
gjorda med iPads, som är så frekvent förekommande i dagens skola att de inte väckte någon större nyfikenhet bland eleverna.

Analyserna baseras på kategorisering i relation till studiens övergripande forskningsfråga med fokus på vad deltagarna gör och uttrycker i de utvalda undervisningssekvenserna. I analyserna är utgångspunkten därmed vad deltagarna säger, gör och menar genom ett deltagarperspektiv (se vidare i Linell, 2011). Det centrala har varit att skapa kategorier och sortera innehållet för att åskådliggöra det fenomen vi undersöker.

Efter datainsamlingen har vi gjort urval av sekvenser från det rika materialet och urvalet skedde i flera steg under tiden som ett analytiskt fokus växte fram. Detta innebär att analyskategorierna inte var förbestämda, utan något som vi inom forskarteamet har arbetat fram tillsammans parallellt med diskussioner om hur social hållbarhet synliggörs $\mathrm{i}$ det aktuella materialet. Fältanteckningarna guidade oss genom filmerna, och var därmed ett stöd vid kategoriseringen. När kategorierna var identifierade påbörjades transkriptionsarbetet, varefter några belysande delar valdes ut. Därefter påbörjades nästa transkriptions- och analysfas av de exempel vi gemensamt valde ut, vilket innebar att filmerna åter analyserades på en mer detaljerad nivå tills vi ansåg att transkriptionsnivån motsvarade studiens syfte och frågeställningar. I analyserna blir det centrala vad deltagarna åstadkommer genom interaktion (Linell, 2011). Corsaro (1982) betonar att transkriptioner är en viktig del av analysarbetet.

För att levandegöra transkriptionerna har även kroppsspråk och aktiviteter som görs samtidigt med tal (se kommentarer inom parenteser) tagits med. Samtalen återges i såväl kortare samtalsutdrag där deltagarnas yttranden markeras med vem som säger vad som genom kursiveringar i brödtexten. Transkriptionerna följer lärares och elevers prat: Tecknet / används för hörbara pauser, medan ? visar frågeintonation och understrukna ord markerar emfas. I samtliga transkriptioner förkortas lärare med L och elev med E.

\section{Resultat}

I denna del ger vi exempel från undervisningssituationer i den insamlade empirin utifrån studiens forskningsfråga: Hur kan lärare som undervisar i naturvetenskaper erbjuda elever mer likvärdiga förutsättningar att utveckla scientific literacy? Resultaten åskådliggörs med stöd av följande kategorier: språkanvändning, konkretisering, tidsanvändning och uppmuntran till elevinitiativ. Varje exempel introduceras med en beskrivning av undervisningssituationen följt av ett interaktionsexempel som därpå tolkas.

De första exemplen är från en biologilektion med det övergripande temat människokroppen. Lektionen rör sig innehållsmässigt inom ett brett spann av naturvetenskapliga begrepp från evolution till blodomlopp. Lärmiljön präglas av arbetsro och nyfikenhet. Läraren använder varierade artefakter för att väcka elevernas intresse för ämnesinnehållet. Efter att läraren har berättat för eleverna om innehållet $\mathrm{i}$ dagens biologilektion uppmuntrar hen eleverna att våga ta del av klassrumssamtalet genom att ställa frågan som exempel 1 åskådliggör: 
Exempel 1: Om man svarar fel

L: vad gör det om man svarar fel / vad händer då?

E: gör inget / ingenting

L: ja det blir ju rätt till slut / eller hur?

Samtidigt som lärarens språkanvändning i exempel 1 är tecken på en öppen lärmiljö med en inkluderande fråga, finns en viss antydan om att alla svar blir rätt till slut. Lärarsvaret kan relateras till de naturvetenskapliga ämnenas karaktär. Många gånger eftersträvas objektivitet och exakthet, och läraren tycks i exempel 1 sträva efter att nå konsensus. Efter denna inledning ställer läraren följande frågor till hela elevgruppen:

\section{Exempel 2: Hur blev vi människor}

L: hur var det alldeles alldeles alldeles alldeles från början / var kommer människan ifrån? / vilka är vi? / var kommer vi ifrån? /alldeles alldeles från början / hur blev vi människor? (elever räcker upp händer) prata två och två (ett pratsurr börjar)

Läraren öppnar i exempel 2 upp för ett organisatoriskt varierat klassrumssamtal. Genom flera öppna frågor flyttas samtalet från lärarmonolog till att eleverna får möjlighet att tala två och två i så kallade bikupor. Tidsanvändningen i exempel 2 visar att efter 43 sekunder vill läraren höra hur eleverna resonerar i bikuporna. Eleverna får således 43 sekunders samtalstid för att två och två diskutera hur människan som art uppstod. Här synliggörs såväl Alms (2010) problematisering om skolkulturens tidsrytm som Vuorenpääs (2016) resonemang om varför brådskan generellt illustrerar skolans undervisningsförlopp och tidsanvändning. Det fortsatta förloppet går delvis i motsatt riktning jämfört med lärarens inkluderande svar (se exempel 1) om att alla svar är välkomna. I detta läge inkluderas endast elever som hinner diskutera frågorna inom 43 sekunder, vilket torde vara problematiskt med tanke på frågornas bredd. Vi som observatörer hinner notera att några av bikuporna inte hinner samtala alls. Två pojkar får ordet och avger tillsammans svaret: apor, vi var först apor. Därefter ger även två flickor exakt samma svar. Läraren summerar därpå denna samtalssekvens med följande konstaterande:

\section{Exempel 3: Vi var först apor}

L: vi var först apor / är det någon som inte tänker att man var först apa / kan vi komma överens om att vi var först apor?

Utifrån den snäva tidsramen för samtalandet i bikupor ges inte alla elever likvärdiga förutsättningar att delta i det naturvetenskapliga samtalet och därmed inte heller att utveckla scientific literacy. Lärarens språkanvändning med upprepat vi-bruk i frågan ovan kan spegla såväl ett strategiskt beslut som en social överenskommelse och hen inkluderar 
därmed eleverna som relevanta deltagare i samtalet med ett gemensamt ansvar. Detta kan tolkas i linje med Wedin (2009) som att läraren har en önskan att vara nära eleverna i gruppen och gör handlingen i sig till ett gemensamt projekt. Samtidigt bortser läraren i just denna sekvens från det faktum att det $\mathrm{i}$ elevgruppen kan finnas olika sätt att se på världen. Elever med olika kulturell bakgrund kan till exempel påverkas av olika religiösa föreställningar och olika sätt att samtala och använda sig av språk. Ett ytterligare dilemma synliggörs genom att läraren använder begreppet $v i$ såväl om det aktuella kollektivet, elever och lärare, som om människoarten. För en del elever blir det svårt att uppfatta att vi också innefattar människans förfäder för miljontals år sedan (som framkommer i en elevfråga nedan). Att kunna skifta mellan olika tidsperspektiv kräver en språklig abstraktionsnivå som alla eleverna $i$ årskurs 5 inte nödvändigtvis ännu behärskar (Skarstein \& Wolff, 2020), och då blir denna dubbla betydelse av vi svår att greppa.

Läraren öppnar upp för ett samtal genom den första frågan i exempel 2 och stänger igen samtalet efter två elevsvar, varefter hen signalerar önskemålet om att alla ska vara överens i exempel 3. Därmed begränsas den dialogiska undervisning i klassrummet som skulle kunna stödja eleverna att utveckla en djupare tankeförmåga (higher order thinking) (Gámez \& Lesaux, 2015; Reznitskaya \& Gregory, 2013). När elever tillåts att argumentera, och även gå i dispyt, ställs de på en mer likvärdig grund trots lärarens, i vanliga fall, kunskapsmässiga övertag.

Bakhtin (1981) betonar att samtal är en möjlig väg för meningsskapande tillsammans, varför samtalsdeltagare blir medproducenter i samspel med andra. Avsikten, enligt Bakhtin, med dialoger är inte att övervinna oenigheter, utan att öppna upp för att diskutera dem. Detta kan relateras till studiens forskningsfråga: Hur kan lärare som undervisar i naturvetenskaper erbjuda elever mer likvärdiga förutsättningar att utveckla scientific literacy? I ett samtalsperspektiv är lärande och kunskap dialogiskt betingat och förutsätter sammanlänkande kommunikationsprocesser där lärande ges potential att uppstå i interaktion. Därmed är det lärarens ansvar att organisera samtal för att ge likvärdiga förutsättningar för alla elever att utveckla scientific literacy.

En elev som uppenbart inte håller med läraren i resonemanget om att vi alla först har varit apor tar ordet och säger: från början var vi först långt långt långt långt långt sedan var vi encelliga organismer. Läraren besvarar därefter inte explicit elevens fråga, men säger några ord om organismer, celler, atomer och molekyler, vilket hen själv efter en stund summerar med:

\section{Exempel 4: Vi kan inte hålla oss till ett ämne}

L: det här är hopplöst med oss / vi kan inte hålla oss till ett ämne (för ihop handflatorna) vi ska titta på en film / kan ni dra ner (rutin i klassen att eleverna drar ner mörkläggningsgardinerna - vilket även görs nu) 
Ainedidaktiikka 4(3) (2020)

Även här (jfr med exempel 2 och 3) ser vi hur läraren i språkanvändningen inkluderar sig själv som en gruppmedlem och hur gruppen inte kan hålla sig till ämnet, även om detta huvudsakligen torde vara lärarens ansvar. Efter denna introduktion och inramning av lektionen pekar läraren mot bildskärmen i klassrummet och frågar vad det är eleverna ser. Flera händer lyfts och en flicka får ordet och svarar att det är en fisk, vilket läraren bemöter med följande yttrande:

\section{Exempel 5: Livet började $i$ havet}

L: det är en fisk ja och precis som E sa så från början var vi bara en pytteliten cell i havet / så livet kom ju faktiskt ifrån havet / allt liv från början

Läraren presenterar sedan en film för elevgruppen där en fiskliknande varelse förändras, går upp på land för att via en apliknande figur bli människa. Läraren återkommer kontinuerligt under lektionen till att tala om apor och hen förtydligar inte om hen avser ordningen primater eller familjen människoapor som arten Homo sapiens tillhör. I detta ser vi att lärarens ämneskunskaper och språkanvändning kan ha stor betydelse för elevernas likvärdiga möjligheter till att utveckla scientific literacy. Efter filmvisningen utspelar sig följande yttranden:

\section{Exempel 6: Hur blev fisken människa?}

E: jag bara undrar när det var en fisk / jag fattar inte / hur blev det så alltså att den utvecklades / att den bara förvandlades till en människa?

L: det var flera hundratals tusentals år (breddar ut armarna samtidigt)

Exempel 6 ovan, inklusive filmvisningen, ger en inblick i komplexiteten när det gäller att välja artefakter som stöder elevers lärande. I detta fall är det kanske inte självklart för eleverna om filmen är tänkt att fungera som en metafor eller inte, vilket kan göra den till en falsk artefakt när den inte motsvarar elevernas kunskapsnivå. Å andra sidan kan den för några elever fungera som en utmaning till nästa kunskapsnivå.

Vi besökte även en femteklass som fick besök av en bakterieforskare. Besöket utmynnade $i$ att eleverna, efter en teoretisk genomgång av vad bakterier är, fick odla bakterier i petriskålar. Samtalssekvensen visar hur forskaren konkretiserar vad bakterier är och hen inleder lektionen med frågan: hur stor är en bakterie och en elev svarar: som en cell. Forskaren håller med och ritar en oval cirkel på tavlan och ritar sedan ett streck och skriver membran. Hen uppmuntrar därefter eleverna att göra en prick på ett papper och följande dialog utspelar sig mellan bakterieforskaren (B), läraren (L) och elever (E): 
Exempel 7: Ser ni pricken?

$\mathrm{B}$ : har ni gjort en prick?

L: ser ni pricken?

B: lite grann / är den svår att se? okey för dom bakterier som du ser här (pekar på ett papper) dom är hundra gånger mindre än (skriver 100 på tavlan) din prick

E: oj så alltså hundra

E: alltså såna där bakterier om man lägger en rad med hundra såna så är det som pricken

B: om du gör / så / hur kan jag förklara / (tar fram tuschpennan) dom är / man säger att två mikrometer om man lägger femhundra i rad i rad det blir en millimeter / vet ni hur stor en millimeter är?

Flera elever: aaa

B: så det betyder att på en centimeter / hur stor är en centimeter? / aa så (visar en centimeter mellan fingrarna) det betyder att man behöver $\underline{5000} \mathrm{i} \mathrm{rad} /$ så dom är ganska små / dom är ganska viktiga för oss för vi har masser av dom / vi pratade om hur många / din egen kropp / och jag tänkte att jag kunde förklara för dig / hur många bakterier vi har i kroppen (suddar på tavlan)

Exemplet ovan demonstrerar hur forskaren med enkla medel, som en prick på tavlan, kan åskådliggöra och konkretisera storleken på en bakterie stegvis, så att eleverna kan se att pricken är 100 gånger större än en bakterie. Efter den teoretiska genomgången tar bakterieforskaren fram laborationsmaterial - en petriskål, en ställning och en plastpåse (för skräp) - och förklarar vad som ska göras och syftet med det hela. Forskaren håller sig sedan kvar i enkla förklaringar och upprepar experimentupplägget i relation till det ämnesspecifika innehållet om bakterier.

Eleverna stöttas både verbalt och multimodalt genom pekningar och fysiska artefakter (Allison \& Goldston, 2018). Centrala begrepp konkretiseras genom detta bakterieexperiment (jfr Ribeck, 2015). Eleverna får i exempel 7 erfara det naturvetenskapliga språket såväl muntligt som skriftligt (af Geijerstam, 2006) och konfronteras med ämnesvokabulären i olika former (Gámez \& Lesaux, 2015).

Ett tredje och avslutande exempel härrör från en femteklass vi besökte som arbetade tematiskt med ett övergripande biologiprojekt där de födde upp höns i klassrummet (se Wolff et al., 2018). Detta påverkade hela skoldagarna, emedan hönsen behövde matas, rastas och skötas på olika sätt. Projektet bidrog till undervisningen med såväl liv som död genom att kycklingarna föddes i klassrummet och de som dog begravdes på skolgården. Projektet inkluderade såväl lärare, elever och föräldrar som andra skolklasser. Fåglarnas existens syntes också i klassrummet utöver hönsburens påtagliga närvaro. En vägg pryddes av elevteckningar från kläckningen, vilka visade att eleverna hade gett fåglarna namn. Alla elever hjälptes åt att sköta djuren varsamt och ömsint. 
Ainedidaktiikka 4(3) (2020)

Eftersom ett elevinitiativ var början till projektet, samtalade vi forskare med initiativtagaren om hur allt började (Wolff et al., 2018). Eleven berättade gärna och ivrigt om projektet. Vi märkte direkt en speciell skärpa i hens sätt att uttrycka sig och språket var mer ämnesspecifikt jämfört med när vi hörde hur eleven uttryckte sig i andra undervisningssammanhang. Även läraren bekräftade denna iakttagelse. Vi frågade om bakgrunden till hönsprojektet och eleven berättade:

\section{Exempel 8: Från ägg till höna}

Först så hörde jag alltså av en kompis till mej att i deras skola har dom gjort sånt. Sen så tänkte jag att varför skulle man inte kunna göra det $i$ vår skola? Och efter det började jag att fråga alltså vår lärare och han sa efter det att en bra idé, föreslå till rektorn och sen så föreslog jag det och hen sa att jo det här är en bra idé och sen behövde vi skaffa sådär pengar så att man kan köpa äggkläckningsmaskinen, men sen kom vi överens med skolan så att dom köpte den för 150 euro och vi köpte inte bara den maskinen utan ett sånt där ruvningspaket med värmelampa, matningsautomat, dryckesautomat och allt sånt, så vi kom igång. Och jag ringde sen till flera bondgårdar för att få tag på ägg. En tupp som vi har kvar föddes regelrätt på beräknad tid och alltså den föddes så att när vi först kom till klassrummet så hade den gjort ett litet hål och sen började den såga som på film ett sågmönster och därefter pluppade den ut och tre överlevde.

Elevberättelsen ovan synliggör hur hönsprojektet startade och hur elevinitiativet uppmuntrades av såväl rektor som lärare (Wolff et al., 2018). Vi forskare följde med lärare och elever till den närliggande skolträdgården där de letade daggmaskar till hönsen. När två pojkar sedan matade fåglarna efter skoltid samtalade de samtidigt med läraren om hur hönsen ska lämnas tillbaka till bondgården när vårterminen är slut. Det blev den initiativtagande elevens uppgift. Vi frågade dessutom läraren om hens upplevelser av projektet. Hen betonade att efter 30 år som lärare hade hen nu valt att arbeta med mångkulturella elevgrupper. Det viktigaste för hen var goda relationer med eleverna.

Sammantaget är hönsprojektet ett exempel på hur socialt hållbar undervisning kan ta form i ett klassrum där undervisningens kärna speglar lärarens värderingar och engagemang (Wolff et al., 2018). Att ha djur $i$ klassrummet aktiverar elever på många olika sätt. Läraren visade en hög grad av tillit till eleverna som speglade den tillitsfulla miljön och hen betonade elevernas inkludering och socialisation framför ambitionen att nå exakt alla skolans ämnesmål. Samtidigt kunde vi som forskare se hur just hönsprojektet särskilt engagerade en elev som annars inte var så intresserad av skolan - initiativtagaren. Läraren betonade att eleven växte rejält under projektet. Eleven använde också ett mer ämnesnära skolspråk än under övrig skoltid i samband med "hens" projekt (se exempel 8). 


\section{Diskussion}

I ett tidigt skede av utbildningen behöver varje skolelev stimuleras till att kunna skilja på olika typer av naturvetenskaplig information, och känna sig inkluderad i ett naturvetenskapligt sammanhang.

Syftet med studien har varit att undersöka hur undervisningen i naturvetenskaper kan förverkligas på ett socialt hållbart sätt. En socialt hållbar undervisning byggs upp i skolans vardag. I ett klassrum skapas många dialoger och i dem möts många olika sätt att se på världen. Vi har i denna studie utgått från forskningsfrågan hur lärare som undervisar i naturvetenskaper kan erbjuda elever mer likvärdiga förutsättningar att utveckla scientific literacy.

I analysen framträdde fyra kategorier, språkanvändning, konkretisering, tidsanvändning och uppmuntran till elevinitiativ, som väsentliga för att undervisningen i naturvetenskap ska bli mer socialt hållbar. Dessa kategorier har vi ställt i relation till tidigare forskning, där vi som ett tvärvetenskapligt forskarteam med bakgrund i flera didaktiska ämnesområden tagit oss friheten att använda olika teoribildningar som utgångspunkter för att underlätta vår gemensamma förståelse av studiens komplexitet.

Hur läraren formulerar sig språkligt och på vilket sätt eleverna stimuleras språkligt får särskild betydelse i naturvetenskapliga sammanhang. Genom att målmedvetet välja diskussionsformer kan läraren uppmuntra elevernas naturvetenskapliga tänkande och språkanvändning (se t.ex. Morton, 2012). Läraren kan också gå in i samtalen och ställa frågor och begära förtydliganden, och på så sätt hjälpa eleverna att tänka utanför sitt vanliga mönster (se Vygotsky, 1978). Undervisningen kan pendla mellan vardagliga uppfattningar och mer naturvetenskapligt baserade fakta. Lärarens roll är att sporra eleverna, så att de utvecklar en förmåga till flexibilitet (Nasir et al., 2006) och kritiskhet (Tan et al., 2012). På så sätt utvecklas det egna ämnesspecifika tänkandet och kunnandet i dialog med andra i en skola som erbjuder eleverna tid att utveckla omtanke och respekt för andras åsikter (Wrigley et al., 2012). Exempelvis visar resultaten, att pronomenet vi kan öppna upp för en rad olika tolkningar utöver den sociala överenskommelsen (Wedin, 2009). Att vi-användningen även kan spegla en samhörighet med människans förfäder för miljontals år sedan ger inblick i ämnesområdets komplexitet. Detta relaterar till behovet av förtydliganden, men även av konkretisering, som också stöds av tidigare undersökningar (Ribeck, 2015; Skolinspektionen, 2017). Resultaten åskådliggör att konkretisering är betydelsefullt för inkludering och för att läraren ska kunna skapa likvärdiga förutsättningar för scientific literacy. I våra empiriska exempel "ser ni pricken" och "från ägg till höna" framkom värdet av modeller, laborationer och autentiska lärandesituationer.

För att utveckla elevernas reflexiva tänkande behövs tillika tid (Jarvis, 2004). I exemplen i den här artikeln framkommer tydligt hur vissa elever inte får en chans att komma fram med sina synpunkter när tiden begränsas. Då finns varken tid för att utveckla egna tankar eller till tankeutbyte med andra. Allra minst finns det tid till att komma med nya 
alternativa tankar. Först när läraren låter eleven uttrycka avvikande åsikter stärks det reflektiva kognitiva lärandet (Jarvis, 2004). Lärare i naturvetenskaper ska också kunna skapa lärandesituationer som tillvaratar elevernas styrkor och intressen och som stöder deras identitetsutveckling (Trauth-Nare, 2016). Genom att göra eleverna delaktiga i undervisningen uppmuntras de att ta egna initiativ och som i exemplet 8 också axla ansvar och därmed växa som individer (Wolff et al., 2018). I detta exempel förenades de fyra kategorierna språk, konkretisering, tid och elevinitiativ i ett lärande som möjliggjorde utvecklandet av scientific literacy. För att läraren ska kunna stödja elevinitiativ krävs ömsesidig tillit, det vill säga att läraren litar på elevernas förmåga och vice versa, samt att läraren generöst öppnar för nya ingångar till kunskap och lärande.

Det är uppenbart att lärarna i vår studie hade olika prioriteringar när det gällde socialisering och ämneskunskap. I det första exemplet (om människokroppen) var ämneskunskapen i centrum, medan hönsuppfödningen prioriterade socialisation och delaktighet. Lärarna gjorde olika didaktiska val utifrån sina mål. Samtidigt var lärarna måna om eleverna, öppna för nya idéer och för samverkan med samhället. De byggde nya relationer och visade att lärande är mer än det som sägs i skolan genom att våga ta in andra aktörer i klassen (forskaren, föräldrarna, andra lärare och andra klasser) (se Wolff et al., 2018; jfr Sund, 2008). Såväl innehåll som socialisering är viktiga i naturvetenskapsundervisningen, men balansgången kan vara svår och kan växla beroende på situationen. I heterogena elevgrupper ska lärarna vara beredda på att ge eleverna tid och vara flexibla i förhållande till de ursprungliga planerna.

Den här studien ger ingen heltäckande bild av hur scientific literacy förverkligas på ett socialt hållbart sätt i skolan. I vår studie framträdde emellertid fyra kategorier som utgör utmaningar för ett likvärdigt lärande. Eftersom lärandet är situerat, är resultaten från våra klassrumsexempel inte direkt överförbara till andra kontexter. Däremot kan de bidra till en förståelse av vad som gör att undervisningen i naturvetenskaper blir mer jämlik och inkluderande. Innehållsmässigt betyder det att socialt hållbar undervisning också beaktar olika epistemologier och kulturell mångfald. Den här artikeln tar inte upp den synvinkeln, men det är ett perspektiv som ger underlag till fortsatta studier. Social hållbarhet ska ingå som innehåll i såväl naturvetenskapliga som samhällsvetenskapliga ämnen, och behöver även förverkligas i praktiken inom samtliga skolämnen. Detta är definitivt en utmaning och kan därför lätt uppfattas som ett onåbart ideal. Ändå är social hållbarhet alltid något som bör eftersträvas. Scientific literacy innebär då inte enbart multimodalt kunnande och att kritiskt kunna ta del av och analysera naturvetenskaplig information, utan att kunna kommunicera och arbeta i mångkulturella miljöer och att förstå hur naturvetenskaperna relaterar till samhället (Allison \& Goldston, 2018). Lärarna i studien visar hur utgångspunkten att naturvetenskaperna är fascinerande, samt att eleverna vill och kan lära sig, ger en god grund för fortsatt lärande. 


\section{Ainedidaktiikka 4(3) (2020)}

\section{Referenser}

Allison, E. \& Goldston, M. J. (2018). Modern scientific literacy: A case study of multiliteracies and scientific practices in a fifth grade classroom. Journal of Science Education and Technology, 27, 270-283. https://doi.org/10.1007/s10956-017-9723-z

Alm, F. (2010). Uttryck på schemat och intryck $i$ klassrummet: En studie av lektioner $i$ skolor utan timplan. (Doktorsavhandling) Linköpings universitet. urn:nbn:se:liu:diva-60227

Bakhtin, M. (1981). The Dialogical Imagination. Austin: University of Texas Press.

Biesta, G. (2003). Demokrati: Ett problem för utbildning eller ett utbildningsproblem? Utbildning \& Demokrati, 12(1), 59-80. https://doi.org/10.48059/uod.v12i1.741

Blikstad-Balas, M. (2016). Literacy $i$ skolen. Oslo: Universitetsforlaget.

Borg, C., Gericke, N., Höglund, H.-O. \& Bergman, E. (2012). The barriers encountered by teachers implementing education for sustainable development: Discipline bound differences and teaching traditions. Research in Science \& Technological Education, 30(2), 185-207. https://doi.org/10.1080/02635143.2012.699891

Boström, M. (2012). A missing pillar? Challenges in theorizing and practicing social sustainability: Introduction to the special issue. Sustainability: Science, Practice \& Policy, 8(1), 3-14. https://doi.org/10.1080/15487733.2012.11908080

Buxton, C. A. \& Lee, O. (2014). English learners in science education. I: S. K. Abell \& N. G. Lederman (Red.), Handbook of Research on Science Education (Vol. 2), (ss. 204-222). New York: Routledge.

Cervetti, G. N., Barber, J., Dorph, R., Pearson, P. D. \& Goldschmidt, P. G. (2012). The impact of an integrated approach to science and literacy in elementary school classrooms. Journal of Research in Science Teaching, 49(5), 631-658. https://doi.org/10.1002/tea.21015

Corsaro, W. (1982). Something old and something new. The importance of prior ethnography in the collection and analysis of audiovisual data. Sociological Methods and Research, 11(2), 145-166.

https://doi.org/10.1177/0049124182011002003

Dawson, E. (2018). Reimagining publics and (non) participation: Exploring exclusion from science communication through the experiences of low-income, minority ethnic groups. Public Understanding of Science, 27(7), 772-786. https://doi.org/10.1177/0963662517750072

Denscombe, M. (2016). Forskningshandboken - för småskaliga forskningsprojekt inom samhällsvetenskaperna. Lund: Studentlitteratur.

Eizenberg, E. \& Jabareen, Y. (2017). Social sustainability: A new conceptual framework. Sustainability, 9(1), 68. https://doi.org/10.3390/su9010068

Gámez, P. B. \& Lesaux, N. K. (2015). Early-adolescents' reading comprehension and the stability of the middle school classroom-language environment. Developmental Psychology, 51(4), 447-458. https://doi.org/10.1037/a0038868

af Geijerstam, A. (2006). Att skriva $i$ naturorienterande ämnen i skolan. (Doktorsavhandling) Uppsala universitet. urn:nbn:se:uu:diva-7352

Helldén, G. (2009). Ämnesdidaktisk forskning om lärande och undervisning i naturvetenskap. I: B. Schüllerqvist, M. Ullström \& S.-O. Ullström (Red.), Ämnesdidaktiska brobyggen: Didaktiska perspektiv inom lärande och forskning (ss. 22-47). Karlstad: Karlstads universitet. urn:nbn:se:kau:diva-4427

Hägerfelth, G. (2004). Språkpraktiker i naturkunskap i två mångkulturella gymnasieklassrum: En studie av läroprocesser bland elever med olika förstaspråk (Doktorsavhandling). Malmö högskola. http://lup.lub.lu.se/search/ws/files/4776824/912899.pdf

Jarvis, P. (2004). Human learning is social learning. I: M. Olssen (Red.), Culture and learning: Access and opportunities in the classroom (ss. 29-72). Greenwich: Information Age Publishing.

Karlsson, A., Nygård Larsson, P. \& Jakobsson, A. (2016). Flerspråkighet som en resurs i NO-klassrummet. Pedagogisk Forskning i Sverige, 21(1-2), 30-55. https://open.lnu.se/index.php/PFS/article/view/1423

Larsen, G. L. (2008). An inquiry into the theoretical basis of sustainability. I: J. Dillard, V. Dujon \& M. C. King (Red.), Understanding the social dimension of sustainability (ss. 45-82). New York: Routledge. 


\section{Ainedidaktiikka 4(3) (2020)}

Laugksch, R. C. (2000). Scientific literacy: A conceptual overview. Science Education, 84(1), 71-94 https://doi.org/10.1002/(SICI)1098-237X(200001)84:1<71::AIDSCE6>3.0.CO;2-C

Lemke, J. (1990). Talking science: Language, learning, and values. Norwood: Ablec Publishing.

Liberg, C., af Geijerstam, A. \& Folkeryd, J. W. (2010). Utmana, utforska, utveckla: Om läs- och skrivprocesser $i$ skolan. Lund: Studentlitteratur.

Linell, P. (2011). Samtalskulturer: Kommunikativa verksamhetstyper i samhället. Volym 1 och Volym 2. Linköping: Linköpings universitet.

Littig, B. \& Grießler, E. (2005). Social sustainability: A catchword between political pragmatism and social theory. International Journal of Sustainable Development, 8(1-2), 45-77. https://doi.org/10.1504/IJSD.2005.007375

McNeill, K. L. (2011). Elementary students' views of explanation, argumentation, and evidence, and their abilities to construct arguments over the school year. Journal of Research in Science Teaching, 48(7), 793-823. https://doi.org/10.1002/tea.20430

Merriam B. S. (1994). Fallstudien som forskningsmetod. Lund: Studentlitteratur.

Missimer, M., Robèrt, K.-H. \& Broman, G. (2017). A strategic approach to social sustainability. Part 2: A principal-based definition. Journal of Cleaner Production, 140, 42-52. https://doi.org/10.1016/j.jclepro.2016.04.059

Moje, E. B., McIntosh Ciechanowski, K., Kramer, K. \& Collaze, T. (2004). Working towards third space in content area literacy: An examination of everyday funds of knowledge and discourse. Reading Research Quarterly, 39(1), 38-70. https://doi.org/10.1598/RRQ.39.1.4

Morton, T. (2012). Classroom talk, conceptual change and teacher reflection in bilingual science teaching. Teaching and Teacher Education, 28(1), 101-110. https://doi.org/10.1016/j.tate.2011.07.006

Mudlay, R. (2020). Re-thinking the integration of socioscientific issues in life sciences classrooms within the context of decolonising the curriculum. I: M. Evagorou, J. Alexis Nielsen \& J. Dillon (Red.), Science teacher education for responsible citizenship: Towards a pedagogy for relevance through socioscientific issues (ss. 173-192). Cham: Springer. https://doi.org/10.1007/978-3-030-40229-7 11

Nasir, N. S., Rosebery, A. S., Warren, B. \& Lee, C. D. (2006). Learning as a cultural process: Achieving equity through diversity. I: R. K. Sawyer (Red.), The Cambridge handbook of the learning sciences (ss. 489-504). Cambridge: Cambridge University Press. https://doi.org/10.1017/CBO9780511816833.030

National Research Council (1996). National science education standards. Washington DC: National Academy Press.

Ødegaard, M., Haug, B., Mork, S. M. \& Sørvik, G. O. (2014). Challenges and support when teaching science through an integrated inquiry and literacy approach. International Journal of Science Education, 36(18), 2997-3020. https://doi.org/10.1080/09500693.2014.942719

OECD (2003). The PISA 2003 assessment framework - mathematics, reading, science, and problem solving knowledge and skills. Paris: OECD.

http://www.oecd.org/education/school/programmeforinternationalstudentassessmentpisa/33694881.pdf

Opetushallitus (2020). Peruskoulun opetuksen ydinasiat. https://www.oph.fi/fi/koulutusja-tutkinnot/perusopetuksen-opetussuunnitelman-ydinasiat

Pearson, P. D., Moje, E. \& Greenleaf, C. (2010). Literacy and science: Each in the service of the other. Science, 328(5977), 459-463. https://doi.org/10.1126/science.1182595

Peko, A. \& Varga, R. (2016). Pupil's initiative in the classroom. Croatian Journal of Education, 18(3), 727-753. https://doi.org/10.15516/cje.v18i3.1608

Reznitskaya, A. \& Gregory, M. (2013). Student thought and classroom language: Examining the mechanisms of change in dialogic teaching. Educational Psychologist, 48(2), 114-133. https://doi.org/10.1080/00461520.2013.775898

Ribeck, J. (2015). Steg för steg: Naturvetenskapligt ämnesspråk som räknas. (Doktorsavhandling) Göteborgs universitet. http://hdl.handle.net/2077/40506

Rieckman, M. (2018). Learning to transform the world: Key competencies in education for sustainable development. I: A. Leicht, A, J. Heiss, \& W. J. Byun (Red.), Issues and trends in education for sustainable development (ss. 39-59). Paris: Unesco. https://unesdoc.unesco.org/ark:/48223/pf0000261445 


\section{Ainedidaktiikka 4(3) (2020)}

Roosa, S. A. (2008). Handbook of sustainable development. Lilburn: Fairmont Press.

Rönnlund, M. (2013). Elevinflytande i en skola i förändring. Utbildning \& Demokrati, 22(1), 65-83. https://doi.org/10.48059/uod.v22i1.985

Sanchez Moretti, G. A. (2015). Education and human rights for sustainable human development. One Pager, 307. https://ipcig.org/pub/eng/OP307 Education and Human Rights for Sustainable Human Development.pdf

Skarstein, F. \& Wolff, L-A. (2020). Species learning and biodiversity in early childhood teacher education. Sustainability, 12(9), 3698. https://doi.org/10.3390/su12093698

Skolinspektionen (2017). Tematisk analys: Undervisning i NO-ämnen. Att göra naturvetenskapen synlig och relevant för varje elev.

https:/www.skolinspektionen.se/beslut-rapporter-statistik/publikationer/ovrigapublikationer/2017/undervisning-i-no-amnen/

Skolverket (2015). Delaktighet för lärande. Stockholm: Skolverket. https://www.skolverket.se/publikationer?id=3531

Skolverket (2016). TIMSS 2015. Svenska grundskoleelevers kunskaper i matematik och naturvetenskap $i$ ett internationellt perspektiv. Rapport 448/2016. Stockholm: Skolverket. https://www.skolverket.se/publikationer?id=7592

Skolverket (2019). Läroplan för grundskolan, förskoleklassen och fritidshemmet. Stockholm: Skolverket. https://www.skolverket.se/publikationer?id=4206

Smith, K. V., Loughran, J., Berry, A. \& Dimitrakopoulos, C. (2012). Developing scientific literacy in a primary school. International Journal of Science Education, 34(1), 127-152. https://doi.org/10.1080/09500693.2011.565088

Southerland, S., Gallard, A. \& Callihan, L. (2011). Examining teachers' hurdles to 'Science for all'. International Journal of Science Education, 33(16), 2183-2213. https://doi.org/10.1080/09500693.2010.530698

Sund, P. (2008). Discerning the extras in ESD teaching. I: J. Öhman (Red.), Values and democracy in education for sustainable development (ss. 57-74). Malmö: Liber.

Tan, E., Barton, A. C., Turner, E. \& Gutiérrez, M. V. (2012). Empowering science and mathematics education in urban schools. Chicago; London: University of Chicago Press. https://doi.org/10.7208/chicago/9780226037998.001.0001

Trauth-Nare, A. (2016). Re-envisioning scientific literacy as relational, participatory thinking and doing. Cultural Studies of Science Education, 11(2), 327-334. https://doi.org/10.1007/s11422-015-9676-6

Uitto, A. \& Saloranta, S. (2012). Aineenopettajat kestävän kehityksen kasvatuksen toteuttajina. I: E. Jeronen, M. Mikkola, H. Risku-Norja \& A. Uitto (Red.), Ruoka - oppimisen edellytys ja opetuksen voimavara (ss. 77-84). Helsinki: Helsingin yliopiston Ruralia-instituutti. http://hdl.handle.net/10138/225810

UN (United Nations) (2015). Transforming our world: The 2030 agenda for sustainable development.

https://sustainabledevelopment.un.org/post2015/transformingourworld/publication

Unesco (2004). The plurality of literacy and its implications for policies and programs: Position paper. Paris: Unesco. http://unesdoc.unesco.org/images/0013/001362/136246e.pdf

Unesco (2012). Exploring sustainable development: A multiple-perspective approach. https://unesdoc.unesco.org/ark:/48223/pf0000215431

Unesco (2019). Right to education handbook. Paris: Unesco. https://unesdoc.unesco.org/ark:/48223/pf0000366556

Utbildningsstyrelsen (2014). Grunderna för läroplanen för den grundläggande utbildningen 2014. Helsingfors: Utbildningsstyrelsen.

Wedin, Å. (2009). Monologen som resurs för språkutveckling i klassrummet i förskola och skola. I: P. Juvonen (Red.), Språk och lärande. Language and learning (ss. 57-69). Rapport från ASLA:s höstsymposium, Stockholm, 7-8 November 2008. Vällingby: Elanders.

Wellington, J. \& Osborne, J. (2001). Language and literacy in science education. Buckingham: Open University Press.

Vettenranta, J., Hiltunen, J., Nissinen, K., Puhakka, E. \& Rautopuro, J. (2016). Lapsuudesta eväät oppimiseen: Neljännen luokan oppilaiden matematiikan ja luonnontieteiden osaaminen. Kansallinen TIMSS-tutkimus Suomessa. Jyväskylä: Koulutuksen tutkimuslaitos. http://urn.fi/URN:ISBN:978-951-39-6874-8 


\section{Ainedidaktiikka 4(3) (2020)}

Wolff, L.-A., Vuorenpää, S. \& Sjöblom, P. (2018). Chicken raising in a diverse Finnish classroom: Multidimensional sustainability learning. Sustainability, 10(11), 3886. https://doi.org/10.3390/su10113886

Wrigley, T., Lingard, B. \& Thomson, P. (2012). Pedagogies of transformation: Keeping hope alive in troubled times. Critical Studies in Education, 53(1), 95-108. https://doi.org/10.1080/17508487.2011.637570

Vuorenpää, S. (2016). Litteracitet genom interaktion. (Doktorsavhandling) Örebro universitet. urn:nbn:se:oru:diva-48343

Vygotsky, L. S. (1978). Mind in society: The development of higher psychological processes. Cambridge, MA: Harvard University Press.

Yin, R. K. (2003). Case study research: Design and methods. London: Sage.

Yore, L. D. \& Treagust, D. F. (2006). Current realities and future possibilities: Language and science literacy - Empowering research and informing instructions. International Journal of Science Education, 28(2-3), 291-314. https://doi.org/10.1080/09500690500336973 